\title{
CLINICAL DECISIONS SUPPORT SYSTEM FOR CHOOSING THE TREATMENT COURSE CHILDREN WITH ENDOCRINOPATHIES
}

\author{
Olga V. Marukhina ${ }^{1}$, Olga G. Berestneva ${ }^{2}$ and Nina P. Stepanenko ${ }^{3}$ \\ ${ }^{1,2}$ Tomsk Polytechnic University, Russia, 634050, Tomsk, Lenina av., 30 \\ ${ }^{1,2}$ Tomsk State University, Russia, 634050, Tomsk, Lenina av., 36 \\ ${ }^{3}$ Institute of balneology and physiotherapy, Russia, 634050, Tomsk, Rosa Luxemburg st, 2 a
}

\begin{abstract}
The object of this research is the problem in children and teenagers overweight. The subject of the study is clinical and laboratorial parameters of the patients. The topicality of the research consists of creation of clinical decision support system to avoid many diagnostic mistakes. It is based on following aspects: the "Modernization of medical health care organization processes with use of information technologies" project is started by the Russian Federation government; there is an important goal to stabilize the part of Russian population with obesity; there are a lot of medical data that should be processed promptly. The novelty of the research is creation of decision-making algorithm for choosing the trajectory of treatment for children with endocrinopathy based on clinical and laboratorial parameters analysis. Clinical decision support system is being operated on the basis of Tomsk Research Institute of Health Resort Study and Physical Therapy.
\end{abstract}

\section{KEYWORDS}

Decision Support System, Medical Multidimensional Dataset

\section{INTRODUCTION}

The healthcare computerization creates opportunities to the clinical decision support system development. In the course of diagnosis, doctor manipulates a considerable amount of data and makes a decision in the context of uncertainty basing upon the first-hand experience and knowledge. IT-solution development for clinical purposes is one of the most promising and efficient ways to prevent these effects. That is why the efforts of many IT specialists are directed to the doctor's heuristics simulating software or expert-based medical decision-making algorithms development. Thus, the objective of this study is to develop clinical decision support system in the choice of treatment tactics (for children with endocrinopathies). One of the most common pathologies of endocrinopathy is obesity.

In 2014, the Government of the Russian Federation declared the list of top-priority research missions that require engaging all available resources. Currently, medical problems can be solved with help of actively developing information technologies. The technologies are covering almost all aspects of medical organizations activities, including management of resources, treatment and medical care. One of the most perspective direction is the development of clinical decision support systems (CDSS). CDSS serve as a basis for fundamentally new approaches creation. The approach solves traditional healthcare tasks such as monitoring a patient, consulting, deciding on further treatment. Studies in this field have been carried out in various directions [Kupeeva I.A. et al, 2015, Greenes R.A. 2007, Litvin A.A. el al, 2014, Ravodin R.A. et al, 2013, Zaripova G.R. et al., 2016, Latypov A.I. et al, 2002, Karpov O.E. et al, 2016, Berner E. S. 2007, Garg A.X. et al. 2005, Kawamoto K. et al. 2005, At'kov, O.YU. et al, 2013, Litvin, A.A. et al, 2016] for 30 years. According to e-Library, the amount of publications on this subject is constantly growing in our country, mostly in the last two years.

Clinical decision support systems serve as a basis for creating fundamentally new approaches to solving traditional problems in health care, such as patient observation, consultation, decision-making on further treatment [Chesnokova I.V. et al, 2007, Nikitina M.I., 2014]. The analysis of scientific publications on this 
topic revealed that the development and research in this area are conducted worldwide and in various directions [At'kov, O.YU. et al, 2013, Najdanov CH.A., 2015, Usov V.YU., 2017, Andersson B., 2011].

Among the Russian developments, the most well-known expert systems are: DIN (emergency recognition) and DIAGEN (diagnosis of hereditary diseases in children). According to the articles, the systems are created for different medical directions. One of the main aspects while working with decision support system data is to decrease the $\mathrm{n}$-dimension attribute space. To solve this problem, the indexes must be selected with respect to their informative value assessment.

The analysis showed that in general, the systems are developed to solve problems related to a specific disease or medical direction. We want to develop a system for selecting a treatment pathway for any disease, provided that there are accumulated statistics on this disease before and after treatment. According to the articles, the systems are created for different medical directions. In this article we will consider the implementation of the system on the example of the problem of treatment of children with endocrinopathy (overweight).

\section{METHODS AND RESULTS}

\subsection{Research Task Description and Solution}

Tomsk Research Institute of Balneology and Physiotherapy provided the following data sets: clinical findings, cardiovascular systemindicators, physical efficiency, lipid metabolism, blood biochemistry, hormonal state, immunological status, blood plasma oxidation capacity and kininogenase system status (fig. 1). The data were received during the clinical studies from 2006 to 2013 and describes 464 children at the ages from 10 to 15 years suffering from obesity. Depending on the degree of obesity, the patient is prescribed a treatment complex (5 complexes in total).

The problem can be solved based on the given data that contain the following groups of basic parameters:

1. Clinic.

2. Cardiovascular system.

3. Physical performance.

4. Lipid metabolism.

5. Blood biochemistry.

6. Hormonal status.

7. Immunological status.

8. The state of the kallikrein-kinin system.

9. Oxidative ability of blood plasma.

10. Immunological Status

In addition to the above indicators, the dataset contains information on the patient's belonging to the treatment group (1-5). To solve the problem, it is necessary to build such a system that could determine for the newly arrived patient the path of treatment for him, that is, one of 5 groups, based on his primary clinical and laboratory indicators.

Mentioned indexes were studied twice: before and after the treatment, as well as their differences and changes were described.

As a result of the research, an algorithm was developed to support the adoption of medical decisions for the choice of treatment tactics for children and adolescents with endocrinopathy (figure 1). 


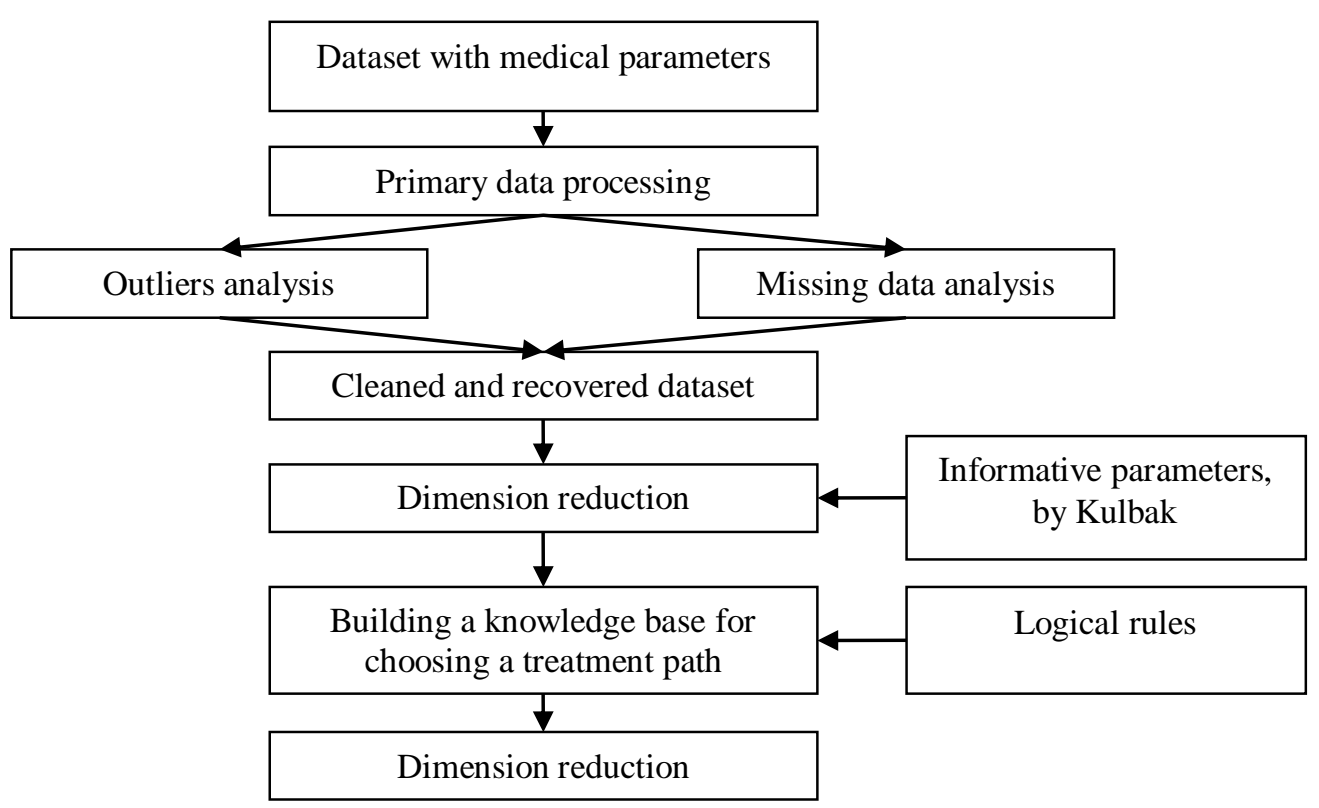

Figure 1. Algorithm for choosing a treatment path

The algorithm consists of the following steps:

1. Array of data. The Tomsk Research Institute of Balneology and Physiotherapy provided baseline data clinical and laboratory parameters of children and adolescents with endocrinopathies.

2. Primary data processing. Next, data was cleared by analyzing the emissions in the RStudio software product and analyzing the missing values using the mean values method.

3. Reduction dimension. To reduce the size of the data, we chose the Kuhlbak informativeness calculation; from the set of features, the most informative in each treatment group were selected.

4. As a result of data cleansing and dimension reduction, a training and test sample was formed to form a knowledge base. As a method for building a knowledge base, a method of building a decision tree was chosen.

5. The decision tree is built in the Rapid Miner software product, on the basis of which we obtained logical rules.

\subsection{Analysis and Imputation the Missing Data}

Missing values and outliers are frequently encountered during the data collection phase of observational or experimental studies conducted in all fields of natural and social sciences. Too many missed values are the problem for further processing and analysis of data. Usually, $15 \%$ from the entire data extraction is the maximum percentage value of missed data. If the amount of percentage value exceeds $15 \%$, it should discard this indicator.

Imputation involves replacing missing values with substituted values obtained from a statistical analysis to produce a complete data set without missing values for analysis. Imputations can be created by using either an explicit or an implicit modeling approach. The explicit modeling approach assumes that variables have a certain predictive distribution and estimates the parameters of each distribution, which is used for imputations. It includes different methods of imputation by mean, median, probability, ratio, regression, predictive-regression, and assumption of distribution. The implicit modeling approach focuses on computing an algorithm required to generate accurate imputation values, if possible. Common implicit modeling methods include hot-deck imputation, cold-deck imputation, and substitution. A combination of explicit and implicit modeling methods is also used.

Identification of missing data is the only unambiguous step. The analysis of the missing data depends on an understanding of the processes that reproduce the experimental information. The function $\operatorname{aggr}()$ from the package mice for R graphically displays the number of observations for each individual variable and for each combination of variables. 

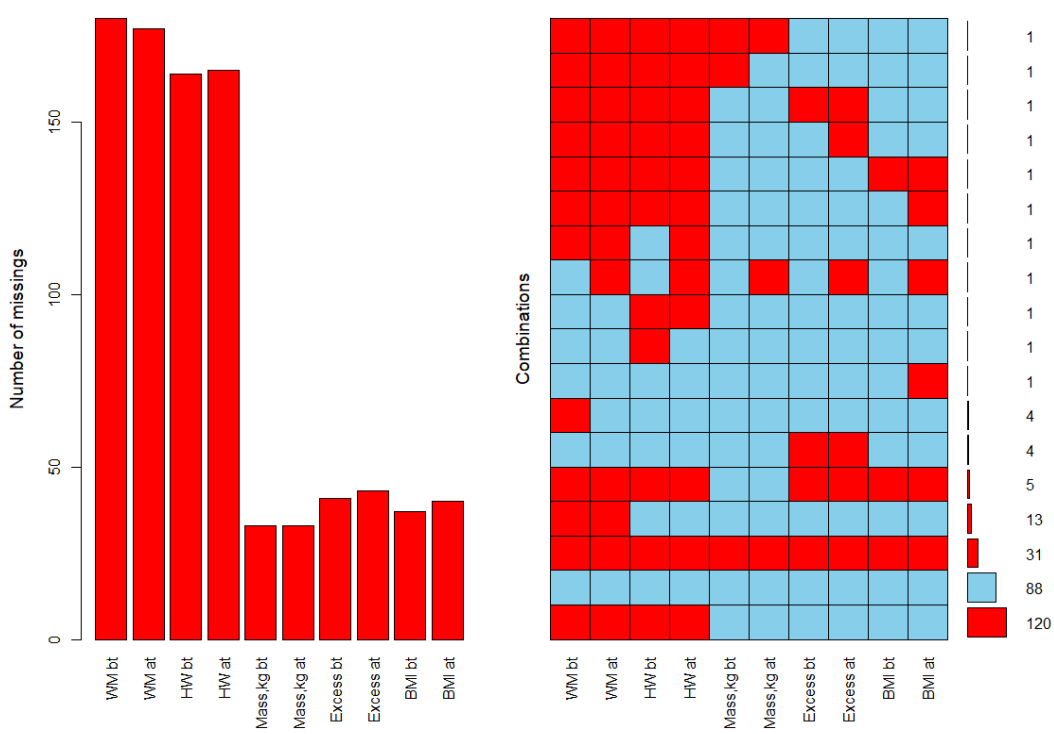

Figure 2. The function aggr() results for dataset which contains the results of the examination of children

Fragment at figure 2 shows that the most missing values are contained in the Waistline before treatment.

The idea of multiple recovery of missing data is well implemented in an $\mathrm{R}$ package like mice. The mice() function (multivariate imputation by chained equations) uses the original data table with missing values, and returns an object containing several complete data sets (five by default). Each such complete data set is obtained by restoring the missing data of the original table. There is a random component in the data recovery algorithm, so all derived complete data sets are slightly different from each other.

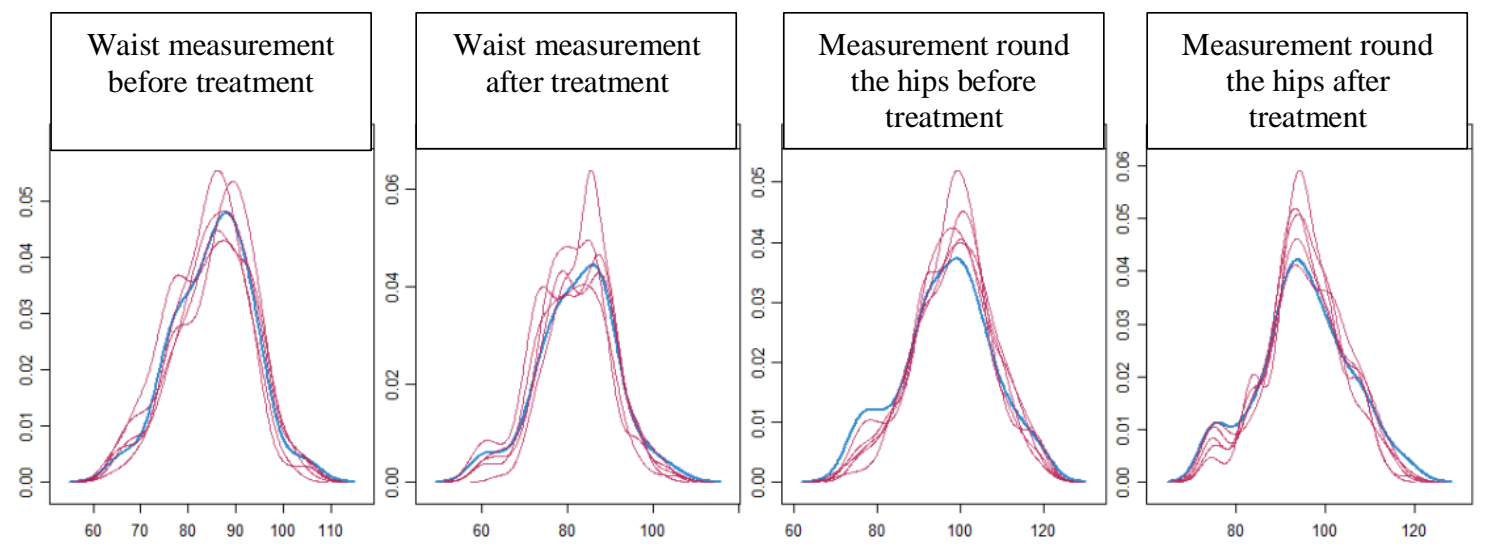

Figure 3. Accuracy evaluation the recovered data

Replacing the missing values is done using Gibbs samples. By default, the values of each variable containing missing values are predicted from the values of the remaining variables. The resulting equations are used to replace the missing data with suitable values.

The user can select the type of predictive model for each variable and define the variables that will be included in it. By default, the correspondence method, the predicted average is used to replace the missing values of continuous variables, and logistic or polynomial logistic regression is used for dichotomous (factor with two levels) or polynomial (factor with more than two levels) variables, respectively.

The result of the function mice() is the base with the restored values. To assess the accuracy of the recovered data, a densityplot(imp) graph was built (figure 3). The density of imputed data for each imputed set is shown in red, and the density of observed indicators is shown in blue. Based on this, we can conclude that the distribution of the recovered data coincides with the original. 


\subsection{Clinical Parameters Informativeness}

Kulback method [Gubler E.V., 1978.] is used to assess the informative value. In medicine, it is possible to deal with the diagnosis issues, establishing diagnosis and medical condition definition only when the informative indexes typical to the patient are obtained and analyzed. Thus, it is necessary to determine the most informative indexes that characterize the patients psychophysical condition. The diagnosis depends on a kind of datamining based on these indexes. There are various techniques to assess the informative value, e.g. Shannon method and the cumulative frequency method, but let us concentrate on Kulback method of informative value assessment.

Indexes informational content depends entirely on how much this index helps to differentiate the object state. The more informative index corresponds to the greater distance between the random variables. The most widespread informative value for these distances is Kulback measure.

In 1948, a logarithmic measure was proposed by N. Wiener and K. Shannon as a way to define the amount of information. They offered the formula that was recognized as information quantitative measure. There is one measure that was introduced by Jeffreus in 1964 and was studied in detail by Kulback as an informative value $J(1,2)$, a measure of discrepancies between statistical distributions 1 and 2 . For discrete distributions, this formula is as follows:

$$
J\left(x_{i} / A_{1}, x_{i} / A_{2}\right)=\sum_{j} \lg \frac{P\left(x_{i j} / A_{1}\right)}{P\left(x_{i j} / A_{2}\right)}\left[P\left(x_{i j} / A_{1}\right)-P\left(x_{i j} / A_{2}\right)\right]
$$

where $A_{1}, A_{2}$ - state classes; $i$-sign number; $j$ - number of $i$-th sign range; $P\left(x_{i j} / A_{k}\right)$ - probability of object hitting belonging to $A_{k}$ class in the $j$ sign range.

In different groups, treatment has different effects on the physiological systems of the body, which has resulted in different informative signs in groups [Marukhina, O.V. et al, 2018].

\subsection{Decision Trees}

One of the methods for representing the knowledge base used in statistics is the decision tree. Decision trees are one of the most popular methods for solving many practical problems, due to the following reasons:

1. Decision trees allow us to obtain very easily interpreted models, which are a set of rules of the form "if..., then...". Interpretation is facilitated, in particular, by the possibility to present these rules in the form of a visual tree structure.

2. Because of their design, decision trees allow you to work with variables of any type without the need for any pre-preparation of these variables for input into the model (for example, logarithm, conversion of categorical variables into indicator ones, etc.).

3. The researcher does not need to explicitly define the form of the relationship between response and predictors, as is the case with conventional regression models. This is particularly useful when working with large amounts of data whose properties are not well known.

4. Decision trees, in fact, automatically select informative predictors and take into account possible interactions between them. This in particular makes decision trees a useful tool for exploratory data analysis.

5. Decision trees can be effectively applied to data with missing values, which is very useful in solving practical problems where missing values are a rule rather than an exception.

6. Decision trees apply equally well to both quantitative and qualitative dependent variables.

To solve the problem of building a knowledge base, a method of building a decision tree was chosen as one of the most popular and giving a good result. To construct a decision tree, we used only informative features, the change of which was the greatest after treatment. The initial data for the construction of a decision tree are informative features obtained as a result of calculating the information content. The percentage of attribution of an object to a particular group is $96.88 \%$ (figure 4 ). 


\begin{tabular}{|c|c|c|c|c|c|c|}
\hline \multicolumn{7}{|c|}{ accuracy: $96.88 \%$} \\
\hline & true group1 & true group2 & true group3 & true group 4 & true group5 & class precision \\
\hline pred. group1 & 21 & 0 & 0 & 0 & 0 & $100.00 \%$ \\
\hline pred. group2 & 2 & 9 & 0 & 0 & 0 & $81.82 \%$ \\
\hline pred. group 3 & 0 & 0 & 14 & 0 & 0 & $100.00 \%$ \\
\hline pred. group 4 & 0 & 0 & 0 & 13 & 0 & $100.00 \%$ \\
\hline pred. group5 & 0 & 0 & 0 & 0 & 5 & $100.00 \%$ \\
\hline class recall & $91.30 \%$ & $100.00 \%$ & $100.00 \%$ & $100.00 \%$ & $100.00 \%$ & \\
\hline
\end{tabular}

Figure 4. Classification assessment

As a result, we obtained a decision tree with the following structure:

- 10 branches. A branch is the rule by which subtrees are obtained;

- 10 subtrees. Subtree - a set of objects obtained from a certain rule.

- 6 leaves. Leaves represent some decision rule regarding the target parameter.

- 5 knots. A node - the place where a tree branching into subtrees occurs; at the time of creating nodes, it is decided how much and how the tree will be expanded.

The decision tree description is presented at figures 5 and 6.

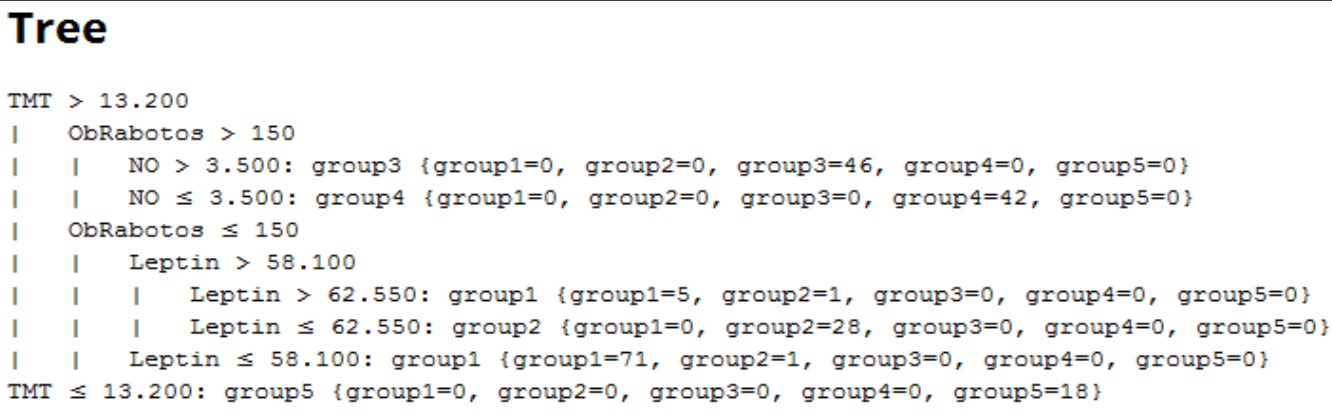

Figure 5. The decision tree description

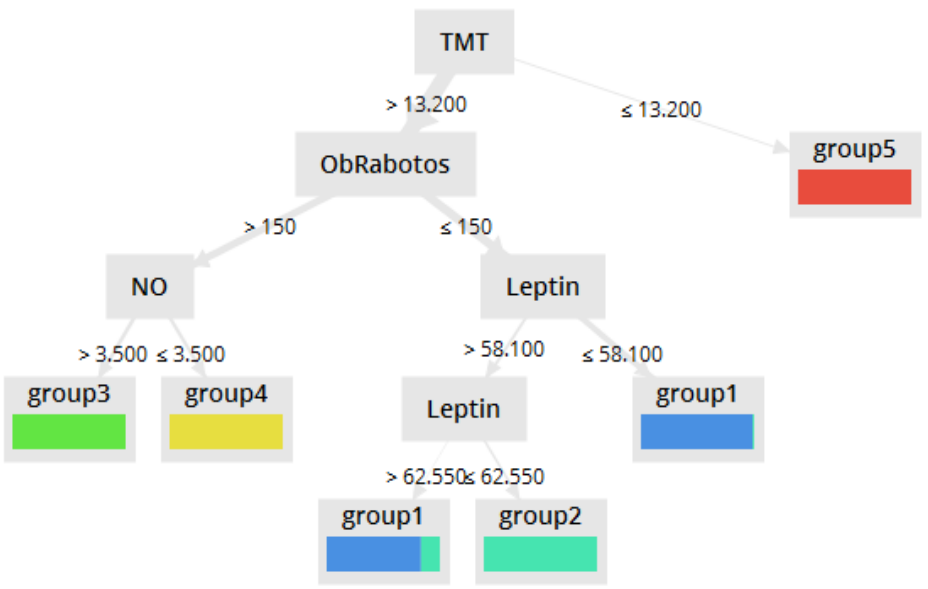

Figure 6. Graphical decision tree view 


\section{CONCLUSION}

Development of systems to support medical decision-making is relevant due to frequent diagnostic errors and incorrect prescriptions of doctors. Mass computerization of health care makes it extremely promising to create systems for algorithmic and information support of medical decisions.

The relevance of our research is due to three aspects:

- the government of the Russian Federation prioritizes the project of the Russian Federation "Improvement of the processes of medical care organization based on the introduction of information technologies»;

- the importance of solving the problem of stabilizing the proportion of the population of Russia with obesity, this is especially important for children and young people;

- a large amount of medical data requires rapid processing.

Based on this, we set and solved the following tasks:

1) we got the dataset of clinical and laboratory parameters of the main physiological systems of the body in conditionally healthy children and adolescents, as well as with various forms of obesity before and after treatment; the problem is solved under the supervision of the Tomsk Research Institute of Balneology and Physiotherapy;

2) informativeness assessment of the main indicators physiological body systems according to the survey results;

3) we constructed the new algorithm for the choice of treatment tactics;

4) unique knowledge base about treatment outcomes based on processing a large amount of data collected at the Research Institute of Resort Medicine and Physical Therapy for several years;

We will continue our research and set ourselves new tasks:

5) building a prognostic model of treatment outcomes depending on the chosen trajectory, forming a knowledge base.

6) the creation of appropriate software, which in the aggregate is an intelligent system with the possibility of its implementation in any medical center conducting such research.

Our system will easily adapt for the decision of tasks of choice of individual course of treatment for any disease subject to the availability of databases of clinical and laboratory parameters before and after treatment. The system will be self-learning, as the database of treatment outcomes will be constantly updated. Another advantage of the system is its convenient use for a medical specialist who is not a specialist in the field of it - it will be an additional electronic assistant for the doctor. On the basis of scientific cooperation, we plan to implement the system in medical institutions free of charge, this is a significant difference from the systems listed in the review at the beginning of this article.

\section{ACKNOWLEDGEMENT}

The study was carried out with the partial financial support of the Russian Foundation for Basic Research (RFBR) within scientific project No. 18-07-00543.

\section{REFERENCES}

Andersson B., 2011. Prediction of severe acute pancreatitis at admission to hospital using artificial neural networks. Pancreatology, 2011. - Vol. 11. -№ 3. - P. 328 -335.

At'kov, O.YU. et al, 2013. Sistema podderzhki prinyatiya vrachebnyh reshenij. Sistemy podderzhki prinyatiya vrachebnyh reshenij. №6, pp. 67-75.

Berner E. S. 2007. Clinical Decision Support Systems. N. Y.: Springer.

Chesnokova I.V. et al, 2007. Sistema podderzhki prinyatiya vrachebnyh reshenij na dogospital'nom ehtape v terapii arterial'noj gipertenzii. Sistemnyj analiz i upravlenie v biomedicinskih sistemah. № 3, pp. 675-679.

Garg A. X. et al. 2005. Effects of Computerized Clinical Decision Support Systems on Practitioner Performance and Patient Outcomes: A Systematic Review. Journal of the American Medical Association, Vol. 293, № 10, pp. 1223-1238.

Greenes R.A. 2007. Clinical decision support: the road ahead / R.A. Greenes. Boston: Elsevier Academic Press. 
Gubler E. V., 1978. Vychislitel'nye metody analiza i raspoznavaniya patologicheskih processov - MEDICINA, Russia.

Karpov O.E. et al. 2016. Primenenie intellektual'nyh sistem v zdravoohranenii. Sovremennye naukoemkie tekhnologii, № 7-1, pp. 38-43.

Kawamoto K. et al. 2005. Improving Clinical Practice Using Clinical Decision Support Systems: A Systematic Review of Trials to Identify Features Critical to Success. British Medical Journal, Vol. 330, № 7494, pp. 765-768.

Knyshov G.V. et al, 2014. Osobennosti proektirovaniya medicinskoj informacionnoj sistemy podderzhki prinyatiya reshenij, osnovannoj na intellektual'nom analize dannyh. Kibernetika i vychislitel'naya tekhnika. № 3, pp.79-87.

Kupeeva I.A. et al, 2015. Razrabotka intellektual'noj sistemy podderzhki prinyatiya vrachebnyh reshenij v dermatovenerologii. Problemy medicinskoj mikologii. Vol. 17, № 3, pp. 27-31.

Kupeeva I.A. et al, 2016. Ocenka ehffektivnosti intellektual'noj sistemy podderzhki prinyatiya vrachebnyh reshenij. Vestnik Sankt-Peterburgskogo Universiteta. №10, pp. 62-68.

Latypov A.I. et al, 2002. Nechetkaya logika v differencial'noj diagnostike stomatologicheskih zabolevanij. Informacionnye tekhnologii v zdravoohranenii, № 8-10, pp.19-21.

Litvin A.A. et al, 2014. Sistemy podderzhki prinyatiya reshenij v hirurgii. Novosti hirurgii, Vol. 22, № 1, pp. 96-100.

Litvin, A.A. et al, 2016. Sistemy podderzhki prinyatiya reshenij v diagnostike i lechenii ostrogo pankreatita. Problemy zdorov'ya i ehkologii. №2 (48), pp.10-17.

Marukhina, O.V. et al, 2018. Basic physiological systems indicator's informative assessment for children and adolescents obesity diagnosis tasks. Journal of Physics: Conference Series. 1015(3), 032091.

Najdanov CH.A., 2015. Sistema podderzhki prinyatiya reshenij dlya preduprezhdeniya riskov vozniknoveniya kriticheskih sostoyanij. Al'manah sovremennoj nauki i obrazovaniya. № 8(98), pp.92-95

Nikitina M.I., 2014. Trekhurovnevaya sistema podderzhki prinyatiya reshenij perinatal'nomu monitoring. Obrazovatel'nye resursy i tekhnologii. Pp. 151-156.

Ravodin R.A. et al, 2013. Intellektual'nye sistemy podderzhki prinyatiya reshenij kak instrument profilaktiki vrachebnyh oshibok. Mediko-biologicheskie i social'no-psihologicheskie problemy bezopasnosti v chrezvychajnyh situaciyah, № 1 , pp. 27-31.

Usov V.YU., 2017. Struktura medicinskoj informacionnoj sistemy podderzhki reshenij, ispol'zuyushchej algoritmy intellektual'nogo analiza dannyh. Vestnik Voronezhskogo instituta vysokih tekhnologij. № 2, pp. 122-126.

Zaripova G.R. et al, 2016. Sovremennye modeli ehkspertnyh sistem podderzhki prinyatiya vrachebnyh reshenij v prognozirovanii operacionnogo riska $\mathrm{v}$ hirurgicheskoj praktike. Tavricheskij mediko-biologicheskij vestnik, Vol. 19, № 4, pp. 140-145. 